\title{
Adaptability, Entrepreneurship and Stakeholder Integration: Scenarios and Strategies for Environment and Vulnerability
}

\author{
Jerónimo De-Burgos-Jiménez ${ }^{1}$, Diego A. Vazquez-Brust ${ }^{2}$, José A. Plaza-Úbeda ${ }^{1}$ \\ ${ }^{1}$ Department of Business Administration, University of Almería, Almería, Spain; ${ }^{2}$ BRASS: ESRC Centre for Business Relationships, \\ Accountability, Sustainability and Society at Cardiff University, Cardiff, UK. \\ E-mail: \{jburgos, japlaza\}@ual.es, VazquezD@cardiff.ac.uk
}

Received July $18^{\text {th }}$, 2011; revised September $26^{\text {th }}, 2011$; accepted October $29^{\text {th }}, 2011$.

\begin{abstract}
The "vicious circle" between poverty and environmental deterioration is a major challenge for those developmental approaches which look to improve the welfare of vulnerable communities. Environmental deterioration increases poverty while, at the same time, poverty causes further environmental deterioration as the business activities which communities depend upon for survival aggravate environmental deterioration by causing pollution and waste. It is therefore necessary that firms and communities collaborate in order to develop innovative solutions to break this vicious circle. This paper argues that such collaboration should be based on genuine stakeholders' integration and entrepreneurship, proposes a holistic framework to guide business intervention strategies, and further explores collaboration scenarios between firms and communities.
\end{abstract}

Keywords: Sustainability, Vulnerability, Sustainability, Stakeholder Integration, Stakeholder Involvement and Entrepreneurship

\section{Introduction}

Environmental deterioration increases poverty in communities living in vulnerable environments or in areas highly contaminated by agricultural or industrial activity, where the productivity of land decreases and the costs of protecting health increase. Although the poor consume little and contribute little to pollution, poverty increases the chances of exposure to environmental deterioration [1, 2], because it creates incentives for weak governance. In such cases, environmental and social problems reinforce each other, giving rise to a so-called "vicious circle" between poverty and environmental deterioration $[3,4]$. In this context, it is very important that both the economic focus and the public dialogue are combined [5]. This paper presents a conceptual framework and strategies intended to break this vicious circle by taking into joint consideration the concepts of stakeholder engagement and integration, entrepreneurship and adaptability.

Poverty, environment, and growth are all central topics of interest for policy makers, academics and other researchers [6]. Studies of poor households and communities suggest that their behaviour with respect to the envi- ronment is very complex [2]. The range of choices and tradeoffs available to the poor is affected by their access to key markets (e.g., for land, labor, credit as well as goods and services) as well as the quality and state of the surrounding environment on which their livelihoods depend [2]. In this context, it is necessary that firms and stakeholders endeavour to develop collaborative practices of dialogue and adaptation [7], but it is also essential that the level of entrepreneurship be high on both sides so that new challenges to sustainability which arise from the competitive global environment and global sustainable development are rapidly faced $[8,9])$. In order to improve the rate of economic development, it is also necessary to suggest how firms should allocate resources towards this objective, how a company must identify intervention issues, how a company has to improve its alliances with stakeholders and how a company has to try to create new markets by supporting entrepreneurs.

The relationship between entrepreneurship and sustainable development is concerned with the link between business and environment. The important role of entrepreneurship is well reflected in the literature as achieving 
a balance between economic viability and environment, and social goals [10]. Thus, a strong link is identified between entrepreneurialism and environmentalism [11] and also between entrepreneurship and social development [12]. This model may help communities to participate in developing successful initiatives [13], as has happened in several initiatives in the sector of eco-tourism [14] or in the well-known example of the Grameen Bank microcredits [15].

Involving the community in businesses is an ongoing process in developing countries [16]. These authors conceptualise Corporate Community Involvement governance as the structures, processes and rules that are socially constructed for organising, coordinating and steering the collective actions of participants involved in CCI programmes. These authors highlight the importance of community interaction and participation to further its involvement in firms, pointing out that this can be achieved by means of a set of activities whose presence the literature has recognised in processes of stakeholder engagement [17] and stakeholder integration [18].

The following sections study in greater depth the problem of the vicious circle between poverty and environmental deterioration and then go on to explore some key factors such as the level of firm stakeholder integration and the level of stakeholders adaptive and entrepreneurship capacity. These key factors may be grouped as internal or external to the firm and by these groupings we may determine the matrix of firm strategies in the natural environment-poverty relationship. We then conclude with some final orientations and recommendations.

\section{The Problem: "Vicious Circle" between Poverty and Environmental Deterioration}

Poverty affects environmental quality and the state of the environment is affected by people's living conditions [6, 19]. In our environment the "vicious circle" between poverty and environmental deterioration is plain to see. Figure 1 shows the vicious circle between environmental

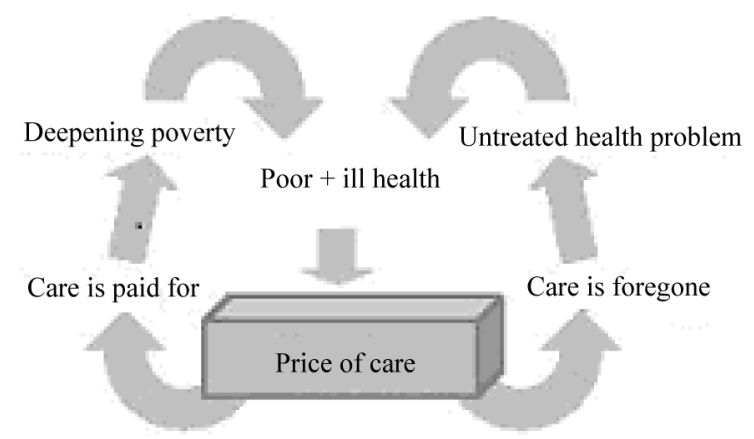

Figure 1. The Medical poverty trap at the household level. Source: [88]. illnesses and poverty.

Civil society demands more responsibility and intervention from the companies to solve social and environmental problems [20]. This can be seen, for instance, in the growing implementation of environmental and social strategies by the companies [21]. However, social and economic vulnerability also operates as barrier to the development of sustainable environmental strategies [22], due to the urgency of reaching a minimal level of economic performance by the companies. The companies working in vulnerable areas tend to be subject to costbased competence, have fewer resources to invest in the environment and have also fewer incentives due to the absence of regulatory or social pressure [23]. In many such cases, proactive solutions, from an environmental point of view are difficult to apply because of their social effects. Cleaner processes tend to use less workers, which increases unemployment, recycling and waste reduction, which in turn can affect, for example, marginal economies that live on informal recycling.

In this context, it becomes necessary to break the vicious circle of the cause-effect connection between negative environmental impact and social vulnerability. It is urgent to find a balance between protecting the environment and decreasing vulnerability, and meeting the interests of companies; and it is important to try to identify, and transmit to every stakeholder involved, tools and/or tactics to reduce poverty and decrease environmental impact in a compatible way.

Despite the diversity of methods and tools for measuring sustainability [24], the incorporation of this concept in mainstream managerial practices has mainly come forward through the so-called Eco-Modernization discourse [25], which acknowledges the need for more integration of environmental issues within corporate management strategy [26] and encourages companies to balance the 'triple bottom line' of economic, environmental and social interests [27]. "Strong” eco-modernization seeks not only to minimise the production of risks but also to prevent their unfair externalisation in space and time [28], thus highlighting social and political aspects which are linked to the environmental conflict [29]. However, insights into social strategies rarely go beyond a general normative framework, indicating intervention areas, nor do they go into detail about the development of specific strategies and practices to practically enhance social sustainability by applying economic and natural capital to greater societal good [21].

Several studies have analysed some resources and capabilities on which environmental strategies can be built to generate competitive advantages. We should highlight organisational learning, continuous improvement, complementarities between innovation capabilities and the in- 
tegration of stakeholders, among others [30-32]. However, these works lack the necessary connection with corporate/business ethics and integration of local communities' problems such as poverty and marginalization.

Since the UN 'Millenium Development Goals' put poverty at the centre stage of global agendas, there has been growing pressure for a higher profile role of business in the matter, triggering a variety of initiatives, some of them already existing in companies long before poverty became a corporate challenge [33,34].

The dominant approach ${ }^{1}$ in dealing with social issues in business is the concept of Corporate Social Responsibility (CSR) which is defined as the voluntary inclusion of environmental and social concerns-such as povertywithin the companies' transactions, and their interaction with stakeholders [35]. However, many authors agree in saying that the practical contribution of business initiatives to reduce poverty has so far been limited and has only worked in particular circumstances [36]. In particular, CSR is not ready to develop solutions to poverty basing itself on the resources and know-how of the companies [37]. The cause for this is the reactive approach in the search for social legitimacy, where the stronger the pressure, the stronger the answer, which leads companies to leave the control of their agenda in the hands of stakeholders, such as NGOs that do not understand the companies' potential capacities. Furthermore, there is no guarantee that the problems claimed by the more vehement stakeholders are the most important ones, and there is a risk of having a never-ending exercise of public relations with minimum value for society and scarce benefit for business [38]. To address these criticisms, an increasing number of authors are working to develop a critical CSR research agenda [39]. As a case in point, 'the enabling environment view of CSR' proposed by [36] stresses the need for a greater integration of community participation, corporate willingness and governmental regulation. Although this perspective is similar to the approach adopted by our proposal, environmental issues do not yet play a central role in "enabling environment CSR". This despite growing recognition that any effective long-term solution to the problem of poverty must also provide solutions to the problems of environmental degradation and depletion of natural resources [40].

Consequently, the analysis of the problems of poverty and environmental deterioration requires a holistic approach that considers the firm's receptiveness to environmental and social issues, and the stakeholders capa-

${ }^{1}$ [41] identify three businesses approaches to deal with poverty reduction: the donor model (i.e. philantropy), the legitimacy model (CSR) emphasing "social licenses" and the market model which frames the relationship between the companies and the poor as a business opportunity (i.e. Bottom of the Pyramid). See [41] for a more detailed discussion of these models and its limitations. bilities to involve a wide range of stakeholders, such as firms, government, communities, NGOs, etc. Recent works are trying to address this gap [4,6,41] adopting theoretical approaches on which to base further studies to improve knowledge of this problem. However these studies have been focused on the analysis of the problem. Following these approaches, we present in the next section a theoretical proposal that, unlike these models, is oriented to address business strategies adapted to different contexts (according social vulnerability and environmental problems).

\section{Theoretical Review}

Having understood the nature of the problem, we are required to analyze some key elements that may influence the relationship between the firm strategy, poverty and environmental deterioration: Stakeholders Theory, Entrepreneurship Theory and Adaptation Theory.

\subsection{Stakeholders Theory}

Stakeholder's Theory proposes a reformulation of the companies' traditional objective of providing dividends to its shareholders, and postulates that businesses must meet all the interests of their stakeholder's [42], described as "the individuals and constituencies that contribute, either voluntarily or involuntarily, to its wealthcreating capacity and activities, and that are therefore its potential beneficiaries and/or risk bearers" [43].

Despite extensive existing research, stakeholders' literature shows a weakness in terms of applicating an integrating vision towards the analysis of environmental and social issues [44]. Practical examples of the use of the Stakeholders theory to propose holistic solutions related to poverty and environmental deterioration are scarce (see for instance [22,45]. However, although at first sight the literature on stakeholders shows a division between the studies of poverty [46] and that of the environment [47] a more careful analysis shows that they draw on the same theoretical concepts and that they offer similar methods for the implementation of social and environmental strategies, which shows the utility of the theory as a general framework for integrating the examination of such concepts.

We identify two aspects of stakeholder theory that are particularly relevant to our analysis of scenarios and strategies to break the vicious circle poverty-environmental deterioration: 1) varied and discrepant issues or interests; 2) normative approaches to develop moral "criteria” for stakeholders management [43].

One interpretation of stakeholder theory is that any firm will have a number of explicit or implicit claims from its many stakeholders. Stakeholders with an "implicit contract” will expect the firm to provide certain compensa- 
tion for the "service" (benefit or contribution) they think are providing to the firm (e.g., a "license" to use natural or community resources). If these expectations are not satisfied, these stakeholders may become litigious and ensure-by legal or other means- that the firm fulfils its duties, thus making the contract explicit. To avoid this, the firm will attempt to meet its implicit claims on a voluntary basis, usually designing a corporate responsibility programme [48]. Emphasising the importance of longterm success, the stakeholder theory suggests that firms cultivate relationships with their stakeholders and integrate these relationships within a comprehensive management strategy. However, there are limits on financial resources that are available for firms to meet stakeholders' implicit claims. Implicit claims grow rapidly, particularly in developing countries, where CSR policies of MNCs tend to fill huge voids in the welfare system. [49: p. 115] argues that, "a company's responsibility often seems to grow even wider in concentric circles, bringing greater territory and increasing the tensions between what they are obliged to account for and what stakeholders feel its fair to take aim at".

Identifying relevant stakeholders and their claims is a first step in the design of collaborative strategies to break "vicious circles". It is not an easy task considering, how flexible and dynamic, is the definition of stakeholders. [50] includes the following groups as main stakeholders: consumers, employees, managers, shareholders, board members, suppliers, buyers, industry chambers, "business clubs", trade-unions, distributors, government officials, judges and courts, legislators, regulators, enforcement bodies, consultants, insurance companies, media, local communities, opinion-makers, the church, vulnerable groups (minorities, the poor), NGOs and civil society.

Thus, it is very challenging for companies to produce long-term social and economic benefits for all stakeholders [51]. Not all stakeholders may attain benefits. Moreover, some stakeholders, particularly vulnerable groups maybe negatively affected by corporate operations [52]. Furthermore, the complexity is added by often conflicting interested between different stakeholder groups, thus satisfying one stakeholder group may lead to dissatisfaction of the others. Whilst some [53] argue that balancing stakeholders' interests is an unworkable objective, others [54] suggest that firms should delineate a rank or hierarchy of stakeholders based on a certain criteria. The interests of stakeholders at the top of the hierarchy are given priority over the rest. The criteria to organise such hierarchy can have an instrumental focus (what hierarchy of stakeholders maximises business benefits) or a normative/moral focus (what hierarchy of stakeholders' is "intrinsically right and responds to the firms" moral values).

Such division between a normative and an instrumen- tal focus on Stakeholder theory [42] caused that [43] makes a difference between what they call the "Stakeholder Management" and "The Management of Stakeholder”. The Management of Stakeholder assumes that the integration of stakeholders must be instrumental to the specific interests of the company, and puts forward a more "manipulative" strategy aimed at convincing or "guiding" stakeholders to align themselves with the company [55]. Thus, according to [17] some stakeholder activities such as stakeholder integration are morally neutral practices, but are frequently applied to social and environmental matters. Stakeholder Integration refers to the ability to establish positive collaborative relationships with a wide variety of stakeholders [31]. Stakeholder integration includes the Knowledge of activities (of the stakeholders, their needs and their demands), interaction between stakeholders and companies, and the adaptation behaviour of the firm to their stakeholders demands. The emphasis is on strategies addressing the wants and needs of those core stakeholders controlling critical resources, information or access to social legitimacy by virtue of their position in a network (employees, customers, local community leaders, suppliers, authorities and investors).

On the other hand, stakeholder management is based on a change in management philosophy that involves new strategies addressing the needs of core and "noncore stakeholders (i.e. the poor, vulnerable, isolated, divergent, non-human) [43]. Aiming simultaneously at current business success and long term survival of the company, this approach has a moral motivation, based on the rightful consideration and integration of stakeholder interests into business decision making [56]. In turn Sustainable Stakeholder Management is a moral approach that emphasises that companies are part of wider ecological and social systems, thus companies' survival depends on the development of harmonious relations with nature and communities. Sustainable Stakeholder Management seeks tools to understand the roles that stakeholders and companies must play in order to combine traditional management goals with sustainable strategies. Accordingly, sustainable stakeholders" management redefines traditional management tools and embeds ethical values in tried and tested "morally neutral" business practices. For instance, "instrumental" stakeholders' integration is replaced by "moral" stakeholders engagement.

Through the Sustainable Stakeholders Management approach the firms may generate new knowledge and innovative solutions $[57,58]$ to complex issues such us reduction of poverty and environmental deterioration. Sustainable stakeholder management provides a "moral" and "instrumental" solution to the issue of conflicting stakeholder interests (or CSR domains). Following, [59] When the interests of various stakeholder groups differ, 
the key to settling those discrepancies lies in identifying which social and environmental approaches allow a better use of a company's resources and have a better set of impacts on the interests of the different stakeholder groups -in our case on the interests of groups imprisoned in environment-poverty traps. The focus has moved from stakeholders' claims to stakeholders' needs and interests; and from stakeholders' management to new models of interaction between firms and stakeholders. In order to confront the problems of poverty and environmental deterioration, therefore, changes must take place implying adaptation to new situations, from the point of view of firms both and their stakeholders.

It follows that current challenges for sustainable stakeholders management are: a) how to identify the needs of stakeholders, b) how to elucidate what social and environmental approaches will maximise the social and environmental impacts of a company's resources and, c) how can stakeholders and companies adapt to the new roles they must play in order to combine traditional management goals with sustainable strategies for the reduction of poverty and environmental deterioration.

Our framework proposes that theories on adaptation and ability to adapt, can help our understanding of strategies addressing such complex challenges.

\section{Adaptation and Ability to Adapt}

Investigations in poverty and sustainability underline the importance of the concepts of adaptation and ability to adapt $[7,60]$.

The concept of adaptation is different in natural science and in social science and although adaptation can be reinforced through adequate planning, it requires social systems to have ability to adapt [61].

A social system's capacity to adapt can be defined as the ability to plan and implement adaptation processes, or, more generally, as the capacity of a human system to modify itself in order to improve, or at least maintain, its member's quality of life against a range of disruptions (present or future) in their physical or social environment.

A human systems' capacity to adapt depends to a great extent on coordinated collective and institutional actions through which efficiency can be enhanced by developing social capital (mutual trust, social integration, community network, rules, consensus and information flow used by individuals both to their own benefit and that of the community) [62]. Other factors are influential such as income level, saving capacity, technology and infrastructure, knowledge and abilities, equity, quality and power of the institutions, access to credit, insurances and employment.

Taking base on the works of $[35,63,64]$ identified se- ven aspects of adaptation capacity which, following sustainability guidelines, relate to the different types of capital existing in the socio-economic planetary systems: human, technological, environmental, man made, social, financial, institutional and natural [65]. Full development of all these adaptive capacities will empower vulnerable stakeholders to emancipate from vicious circles of poverty and environmental deterioration.

The role of the company in the development of these dimensions of adaptive capability is clearly paramount, and it becomes necessary, for example, to work towards increasing the cooperation between global and local approaches; to offer wider information about the most vulnerable areas and groups [66]; to make investments aimed at improving access to drinking water and sanitary infrastructure [64]; to develop innovative approaches in order to reinforce saving capacity and access to micro credits; to invest in the development of technologies adapted to natural resources, etc.

Thus, a "normative" criteria to stakeholders management will demand two conditions in all firm-stakeholders' relations: "Doing no-harm" implies that none of the stakeholders see their adaptive capabilities harmed by the firm's actions. "Doing good" requires preventing the deterioration of stakeholders' adaptive capabilities by impacts outside of the companies [29].

So far, our framework has identified the central criteria that should guide stakeholders' management to assure its moral goals. The problem is that good intentions and aims are not always translated into successful strategies and outcomes. Thus, we need a third pillar in our theoretical framework to help us conceptualise what conditions are required if firms and communities to succeed in the development of dimensions of adaptive capability. We argue that a most important condition is entrepreneurship.

Adaptation theories emphasise the central role of social capital and the importance of social entrepreneurs to enhance social capital. In turn, as we will see in the next section, entrepreneurship is the key to mobilise the strategies and alliances required to unleash adaptive capabilities in firms and their stakeholders.

\subsection{Entrepreneurship}

Entrepreneurship is universally acknowledged as playing a leading role in economic growth [12] and there is growing evidence to suggest that there is a significant causal relationship between entrepreneurship, economic growth and poverty reduction [67].

Entrepreneurship is a promising field of research which has its framework in the relationship between opportunity and the entrepreneur [68]. However, [69] pointed out that the progress of this field has found problems of definition 
because researchers often try to analyse a phenomenon that cannot properly be defined. As a result, much entrepreneurship research is fragmentary and focuses narrowly on particular aspects of entrepreneurship.

[70] suggest a continuum of entrepreneurial opportunities ranging from codified to tacit. They find that relatively more codified opportunities are more likely to be discovered through systematic searches, whereas more tacit opportunities are more likely to be identified due to prior experience. Collaboration with local communities and stakeholders may help to acquire this tacit knowledge [71]. This knowledge is the basis of entrepreneurial opportunities that are context specific and are difficult to imitate [70].

The economic exploitation of these opportunities may reduce poverty problems [72]. Moreover, this knowledge gives rise to greater corporate proactivity. Proactivity recognised in the literature as an essential component of entrepreneurship [73] has been closely linked to the development of proactive environmental strategies [32]. It has been claimed that Entrepreneurship reduces both environmental degradation [74] and social problems [41]. Accordingly, reformulating a definition used by [74] to include social aspects, sustainable entrepreneurship can be defined as the process of discovery, evaluation and exploitation of the economic opportunities present in the market flaws which hinder sustainable development, including those related to environmental and social issues.

Such a definition provides a theoretical link between risk, vulnerability and entrepreneurial activity. [65] note that for entrepreneurs to be able to exploit the opportunities arising form a shock, there must exist certain barriers that prevent other (for instance, large firms) from making use of those opportunities. [66] explain that, in vulnerable social systems, such barriers are the lack of information within large firms about the social systems in the affected communities; perception of risk, capacity to adapt, and social acceptation are key points to define the acceptance of a new product.

[41] recommends that the private sector contributes to the development of entrepreneurs' initiatives through empowerment ${ }^{2}$, offering education and training, investing in basic services projects and facilitating access to natural and financial resources (safe credits). [75] believe that private companies interested in entering markets where the poor are the majority, must constitute strategic alliances with stakeholders who have access to the human and social capital of the vulnerable communities, particularly NGOs or micro companies set up by local

${ }^{2}$ Empowerment: ability of people, in particular the least privileged to a) have access to productive resources that enable them to increase their earnings and obtain the goods and services they need, b) participate in the development process and the decisions that affect them, c) have access to information [76]. entrepreneurs, but also SMEs and local authorities in what is called the new "social compact". Additionally, [75] suggest that it is for the company to integrate environmental issues within the framework of its alliances and support for entrepreneurs.

A tendency of many managers to filter market signals that imply a necessity for change, particularly in environmental issues can negatively affect the performance of alliances [77], hence, companies must at the same time try to promote internal environmental entrepreneurship. Likewise, political and institutional obstacles can frustrate the exploitation of opportunities, increasing transactional costs (intermediaries, corruption, bureaucracy) and also in this case, institutional entrepreneurs (technologies such as the "chemical digital fingerprint", which provide evidence of the originator of a communication, or lawyers who can collectively represent all those affected by an environmental catastrophe) or politicians (government employees who can modify subsidy or tax systems) who can influence the political and economic systems, are the most adequate stakeholders to integrate within the companies' management.

To sum up, the third contribution of this framework is the necessary emphasis in promoting a sustainable entrepreneurship as a link and lever between the companies and their stakeholders within proactive managerial strategies.

\section{Scenarios in Sustainable Relationships}

In order to better understand a firm's strategy on poverty and the natural environment, we define a matrix to look at different actuation scenarios in connection with two axis. One Axis reflects the "Stakeholders" dimension of our holistic framework (The company's Stakeholders Integration Focus). The second reflects the "Adaptation" dimension of our framework (Engagement Capability of Communities where the firms operates). These axis condition the type of strategy adopted by the company and their effect on sustainability. The Entrepreneurship dimension of our framework is intimately related to both axis. Entrepreneurship is a driving force of engagement capabilities but it is also an important influence in the development of stakeholders integration focus.

The Sustainable Stakeholders Integration Focus axis contains the intensity and scope of the firm stakeholder's integration strategies and it also reflects the intensity and scope of the firms environmental and social intervention strategies. The Engagement Capability of Communities is measured by their adaptive capabilities and entrepreneurship skills along with the intensity and scope of the relationships among them. Although both dimensions may be a continuum, we adopt a simplified scheme that classifies each of them in two categories: high and low. The strategies associated with each possible scenario would 
be Monitoring Strategies, Defensive Strategies, Mentorship strategies and Integration strategies (see Figure 2).

Monitoring Strategies: These emerge when a company lacks the capacity or interest for implementing sustainable stakeholders management, and the stakeholders do not set up alliances, or lack entrepreneurship and any capacity to adapt to improve environmental and social conditions.

In this context, the effectiveness of voluntary actions in solving complex social problems is limited. There is no communication, the company does not understand or does not want to understand the justification or legitimacy of stakeholders' claims, and lack the ability to make their necessities heard. This is the case of the so called "marginalized stakeholders" [78] describing the Australians aborigines" attempts to prevent their land from being used for mining. [79] argues that the inability to act arises from a lack of mobilization structures, that is, a lack of adaptive and entrepreneurship capabilities.

Defensive Strategies: When a company does not have a focus on the integration of community stakeholders, but communities have high levels of adaptive capabilities and entrepreneurship, the company's strategy will respond to the intensity of pressure exerted by communities, and the resulting scenario will be one where the main efforts go towards issues related to those community stakeholders with stronger power over the company. Since there are multiple stakeholders with multiple interests, whom interests prevail will depend on the relationships of power and influence strategies [38]. Not taking stakeholder demands into account and considerations at an early stage may cause problems regarding a lack of information. On the one hand, a firm may miss possible opportunities, and on the other side, certain drawbacks (e.g. possible environmental problems) may not become apparent until the negative consequences have appeared and the cost of solving them is very high.

The case of the mining company Meridian Gold in the locality of Esquel (Argentina) had far more adverse consequences for the firm. Meridian Gold had neither strategies nor any willingness to integrate their stakeholders or to adapt their practices to address the community's concerns about the use of cyanide in the mines. However, they confronted a community which was well organised and educated, with high social and human capital built around a local economy based on activities other than mining (agriculture, tourism, services). As a result, not only did the firm have to leave the country, but also the use of cyanide in mining was legally prohibited in the region.

The limited effort in stakeholder integration may also result in missing tacit entrepreneurship opportunities [70]. Although the stakeholder integration initiative is usually based on the enterprise level, some firms may be sur-

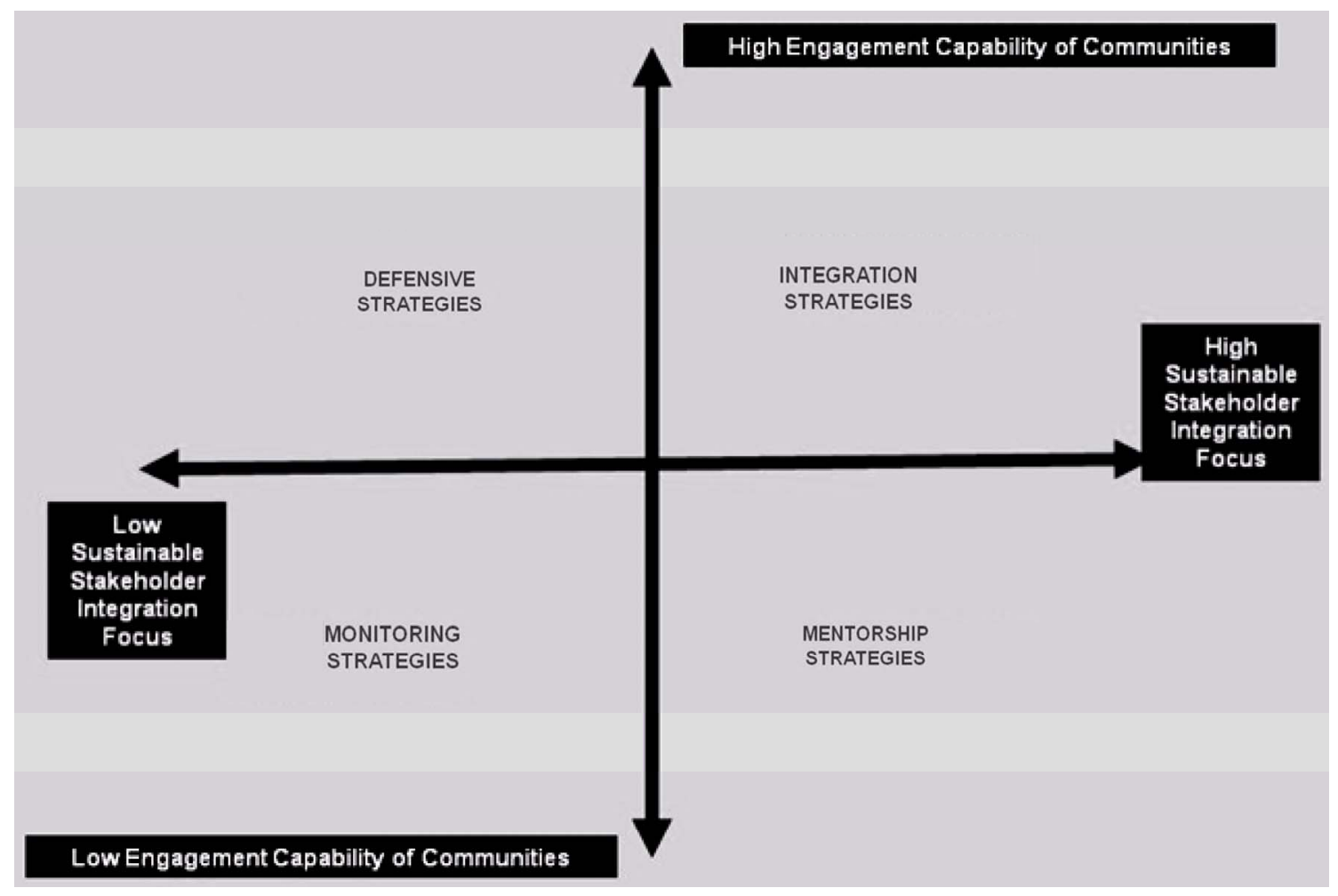

Figure 2. Strategies for the firm. 
prised by stakeholder collaboration and cooperation that result in the creation of news firms to exploit these opportunities (e.g. the microcredits and the development of the Grameen Bank). In early stages the new firms are not operating in the same market as existing enterprises, but these new firms may evolve and become serious competitors.

Mentorship Strategies: If the firm is strong in its sustainable stakeholder integration focus, but the communities are weak in adaptation capacity and entrepreneurship, the company will be capable to guarantee the stakeholders' integration in the dialogue, but the stakeholders will not be able to fully benefit from such integration. The company has to use its capacity to strengthen the stakeholders through tangible and intangible capital, training, foundations, and maybe product stewardship with local suppliers and also through an active search for stakeholders qualified to contribute to this task (NGOs, Universities, and commercial associates). In these cases, the firm has the initiative to engage local communities which may benefit from an improvement in their social outcomes (public health, emergency relief...) and the firm may as a result acquire some benefits such us improving risk management, increasing social legitimacy and better employee attractiveness [80]. However, there is a danger of developing a dependency of the firm resource and that the areas of improvement are mainly firm oriented.

The selection of practices will be based on necessity/ legitimacy interpretation internal criteria, and it is possible that, initially, the efforts aimed at improving the environmental impact will be more developed, due to the positive effect over performance (for example in production), because the company can more clearly see the effect over performance on environmental initiatives than on initiatives linked to social vulnerability.

A successful example of mentorship strategy is the alliance established by British Petroleum (BP) with three micro-credit companies in India for the distribution of a portable oven which uses both liquid fuel and biomass. The innovative device responded to a need of poor communities to switch to bio-mass in economic scarcity, while avoiding toxic fumes release. BP was responsible for introducing environmental, hygiene and security standards as non negotiable requirements, while at the same time providing the necessary training to their local partners through a partnership with community's NGOs. The micro-credit companies on the other hand, once empowered by training, maximised their ability to bring in the partnership their knowledge of local needs and resources, in turn enabling BP to design suitable solutions and make the product available to isolated rural communities [75].

Integration Strategies: If the capacities of both companies and communities are strong, the conditions exist for a society with full integration of community stakeholders within a firm, and with the firm acting as just another stakeholder for solving complex social problems, using its experience and knowledge to develop entrepreneurial projects with local stakeholders and to invest in sustainable entrepreneurs or the acquisition of natural capital.

When more powerful community stakeholders form coalitions, there is a risk of marginalizing those who are more vulnerable or who remain excluded from the coalition. In this case, the company must carefully organise mechanisms to adequately search consensus in order to minimize the effects of relationships of power and influence strategies and, at the same time, try to strengthen the weaker or marginalised stakeholders. Under these circumstances, there is a possibility of attaining a balanced intervention strategy that proposes integral solutions for social vulnerability or environmental impact combining the capacities of all the involved stakeholders.

These type of strategies may result in stable joint benefits to firms and communities. The main benefit is usually a shared accountability of the problem and shared vision of solutions, but sometimes it is possible to transform the problem domain itself or to generate new knowledge resulting in new product development or efficiency improvements $[58,80]$.

[14] shows the success of an ecotourism initiative to protect the environment and preserve the livelihood of local communities: The Shark Reef Marine Reserve in Fiji. It involves the local communities and all relevant stakeholders in an area where marine rights are finely subdivided into small units. The local villages have exchanged their traditional fishing rights in the marine reserve for a new source of income through diver user fees. The strategies outlined in the previous paragraphs are not static; on the contrary, they could be seen as phases of a process in which the integration strategy represents the result of sustainable development. The continuity of this process requires education and training of companies and stakeholders in order to understand the importance of promoting entrepreneurship, reinforcing adaptation capacities and working towards the integration of stakeholders, aimed at searching consensus.

\section{Discussions and Policy Recommendations}

More vulnerable sectors, although underprivileged, are not unimportant for firms; quite the opposite: They sometimes become key allies for the success of numerous initiatives [22]. Our first recommendation is aimed at guaranteeing the participation of all the stakeholders. We introduce some general considerations in order to increase the integration of this non financial stakeholder (employees, supplies, customers, communities):

- Promoting engagement and mutual knowledge be- 
tween firms and stakeholders (especially community stakeholders, those more underprivileged and NGOs).

- $\quad$ Promoting the use of dialogue and communication tools between the main agents responsible for environmental pollution and those groups who are especially vulnerable.

- Improving the capacity to implement activities and/ or projects in those areas that are more vulnerable to environmental impacts and to adverse socio economic conditions.

- $\quad$ Setting up adaptation mechanisms for both firms and stakeholders, in an attempt to reconcile their interests and objectives in the short and in the long term.

- Including the promotion of sustainable entrepreneurship within an organization and in the social and institutional context as a part of the strategic vision of the firm's sustainability. Sustainable entrepreneurs are seen here as leverage for the development of proactive company strategies.

Secondly, a company must identify issues of intervention while managing the multiple and, occasionally, "quasi” incompatible demands of different stakeholders [42]. As mentioned above, there are certain strategies which intend to manage the negative impacts of the firm (doing no harm) and other strategies destined to solve generic problems which are not created by the firm (doing good).

Our suggestion is that the "No harm" approaches must change so as to follow the precautionary principle and not carry out activities unless it is guaranteed that they will not cause harm, instead of reactively discontinuing activities only when it becomes scientifically proven that some harm has been caused. On the other hand, "Doing Good" strategies ought to be selected on three successive criteria to increase their effectiveness:

- Contribution to the reinforcement of social cohesion.

- Better "fit" with the organizational culture.

- $\quad$ Selection of those strategies that make a more efficient use of the companies' resources.

The criteria of "fitting in with the organization's culture" and of a more efficient use of the company's resources, lead us to suggest that a higher effectiveness of voluntary actions would be reached by focusing the company's voluntary intervention on the market model and, in particular, in the formation of alliances with stakeholders and the creation of new markets through supporting entrepreneurs, both within the company and in the social systems where social and environmental vulnerability prevail $^{3}$ [41] In this sense, we mention some general recommendations: a) To minimize the company's negative impacts while selecting areas for intervention, in order to provide solutions whereby the company can maximize the use of its available resources, organizational capacity and expertise.

b) To build relationships with local stakeholders, and integrate local and global stakeholders in the firm's decisions and strategies.

c) To improve channels of communication and to implement innovative mechanisms aiming at a democratic search of consensus among stakeholders ${ }^{4}$.

d) To improve the quality of investments generating added value in the country without affecting the environment.

e) To develop new Technologies and practices that adapt to the resources available for the more vulnerable, and to move from the provision of goods to the provision of services [82].

f) To cooperate in the diffusion of sustainability values, offering information and practical implementation guidelines for those stakeholders identified as priority either because of their vulnerability or because of their capacity of leverage.

g) To integrate local entrepreneurs in the above strategies, and to encourage processes of sustainable entrepreneurship within the companies and in economically and socially vulnerable communities.

Mechanisms and enforcement of compliance with compromises, comparability in the information, and standards and implementation of mechanisms for the access of the least powerful stakeholders to deliberation. This requires the firm to have a clear vision and politics, developing standards and systems of environmental and social performance monitoring and specific leadership, organization and dialogue capacities.

Likewise, all the stakeholders and, in particular, the most vulnerable ones, along with NGOs, must have a capability of adaptation to join into dialogue with the company [83]. In this context, adaptation capability is redefined as the "ability of the social actor to complement, and utilize the expertise of, the company in pursuit of the partnership goals" [13,84].

All of the above reinforces the idea that stakeholder management, beyond any rhetorical considerations, is a

\footnotetext{
${ }^{3}$ We do not exclude that the company can at the same time profit through these interventions, but the point is that the main goal must not be economic or Public Relations profit.

${ }^{4}$ An example of this can be the use of the Delphi methodology, which was designed in the first instance to overcome the difficulties found with traditional forms of consensus through conduct of a round table discussion [81]. Within Delphi, consensus can be sought through sending a quantitative analysis of the results back to respondents and asking those respondents who give an answer outside of the mean response to either change their forecast estimation, or to provide justification for their stance.
} 
necessary element for the long-term survival of organisations, even more so in situations in which poverty and environmental degradation are pressing problems. Nevertheless, there is a long way to go in this respect, since many firms focus on visible aspects of Stakeholder Management and CSR rather than on the true impact of their actions on society.

The model of micro-credits which has been successfully implanted (initially in poorer countries and later all over the world) is a good example of the possibilities that entrepreneurship and stakeholder management offer to solve the problem of poverty. However, it is not enough to develop corporative citizen behavior

However, in order to maximize the results of the stakeholders management, the company must create a deliberative environment where there is transparency in the discourse, monitoring which implies progressing from "doing no harm" to "doing good" [85]. There is a need for the explicit inclusion of protection of the natural environment in which corporate activity is developed to enable the long-term sustainability of socio-economic systems. On the one hand this may mean a restriction in the areas of activity in which collaboration is possible, but it also opens up business possibilities, since the residues of one firm may provide the main input for another one. This occurs, for example in the systems of industrial ecology which have been implanted in developed economies [86].

As [15] points out, the change of economic models to escape poverty can only come about with a change in the mindset of the agents involved to accept and take on board these values. Likewise, these aspects can be extrapolated to the relationship between poverty and environment [35].

\section{Conclusions}

Poverty and the natural environment have a two-way relationship. On the one hand, natural environment affects poverty situations in three ways: by providing sources of livelihoods to poor people, by affecting their health and by influencing their vulnerability [19]. On the other hand, poverty may also induce societies to downgrade the natural environmental in various ways: forcing poor people to degrade environment, encouraging countries to promote economic growth at the expense of environment, and stealing resources from the protection of the natural environmental $[2,87]$.

The stakeholder theory is the umbrella under which we develop strategies to break this vicious circle. Firm's strategies promoting integration and engagement of stakeholders, especially local communities, can help to overcome this situation. However, the success of the strategies depends also on the existence of stakeholder adaptation capability and entrepreneurship. The combinations of these elements in a double entrance matrix configure four different scenarios. Each scenario is defined by a specific type of corporate strategy: Monitoring, Defensive, Mentorship and Integration Strategies. The latter represent the only scenario where synergies between community and company can be unleashed and applied to destroy vicious circles poverty-environmental deterioration.

This inspires some of our recommendations (and commentaries): a smart mix of "doing no harm" and "doing good" criteria to be applied as guidance to reinforce the adaptive capabilities of firms and stakeholders; investment in company initiatives promoting entrepreneurship in a variety of forms (in the company, in society, in research) and investments to develop stakeholders engagement skills within the company but also in the community.

\section{Acknowledgements}

The present paper is part of the theoretical development made within the International Investigation Project called "Environmental impact of companies, social vulnerability and poverty in Latin America: Interaction analysis and diagnosis of areas potentially at risk", financed by the Spanish Agency of International Cooperation (AECI) (reference A/017735/08). This work has been partially funded by the Spanish Ministry of Science and Education and the European Fund for Regional Development (reference ECO2008-03445/ECO).

\section{REFERENCES}

[1] S. L. Hart, "A Natural-Resource-Based View of the Firm," Academy of Management Review, Vol. 20, No. 4, 1995, pp. 986-1014.

[2] E. B. Barbier, "Poverty, Development, and Environment," Environment and Development Economics, Vol. 15, No. 6, 2010, pp. 635-660. doi:10.1017/S1355770X1000032X

[3] H. Todd and C. Zografos, "Justice for the Environment, Developing a Set of Indicators of Environmental Justice for Scotland,” Environmental Values, Vol. 14, No. 4, 1995, pp. 483-501. doi:10.3197/096327105774462692

[4] M. E. Ibarrarán, M. Ruth and S. Ahmad, "Climate Change and Natural Disasters, Macroeconomic Performance and Distributional Impacts," Environmental Development Sustainability, Vol. 11, No. 3, 2009, pp. 549-569. doi:10.1007/s10668-007-9129-9

[5] M. Toman, "Values in the Economics of Climate Change," Environmental Values, Vol. 15, No. 3, 2006, pp. 365-379. doi:10.3197/096327106778226310

[6] H. Khan, "Poverty, Environment and Economic Growth, Exploring the Links among Three Complex Issues with Specific Focus on the Pakistans Case," Environmental Development Sustainability, Vol. 10, No. 6, 2008, pp. 913-929. doi:10.1007/s10668-007-9092-5 
[7] B. G. Norton, "Pragmatism, Adaptive Management, and Sustainability,” Environmental Values, Vol. 8, No. 4, 1999, pp. 451-466. doi:10.3197/096327199129341914

[8] G. Keijezrs, "The Transition to the Sustainable Enterprise,” Journal of Cleaner Production, Vol. 10, No. 4, 2002, pp. 349-359. doi:10.1016/S0959-6526(01)00051-8

[9] M. Wissenburg, "Global and Ecological Justice, Prioritising Conflicting Demands,” Environmental Values, Vol. 15, No. 4, 2006, pp. 425-439. doi:10.3197/096327106779116131

[10] A. Menon and A. Menon, "Enviropreneurial Marketing Strategy, the Emergence of Corporate Environmentalism as Market Strategy,” Journal of Marketing, Vol. 61, No. 1, 1997, pp. 51-67. doi:10.2307/1252189

[11] S. Dixon and A. Clifford, "Ecopreneurship-A New Approach to Managing the Triple Bottom Line,” Journal of Organizational Change Management, Vol. 20, No. 3, 2007, pp. 326-345. doi:10.1108/09534810710740164

[12] A. Zapalska, G. Perry and H. Dabb, "Maori Entreprenuship in the Contemporary Business Environment," Journal of Development Entrepreneurship, Vol. 8, No. 3, 2003, pp. 219-235.

[13] M. Leach, R. Mearns and I. Scoones, "Environmental Entitlement, Dynamics and Institutions in CommunityBased Natural Resource Management," World Development, Vol. 27, No. 2, 1999, pp. 225-247. doi:10.1016/S0305-750X(98)00141-7

[14] J. M. Brunnschweiler, "The Shark Reef Marine Reserve, a Marine Tourism Project in Fiji Involving Local Communities,” Journal of Sustainable Tourism, Vol. 18, No. 1, 2010, pp. 29-42. doi:10.1080/09669580903071987

[15] M. Yunus, “Es Posible Acabar con la Pobreza?” Editorial Complutense, Madrid, 2006.

[16] R. S. Gregory, "Incorporating Value Trade-offs into Community-Based Environmental Risk Decisions," Environmental Values, Vol. 11, No. 4, 2002, pp. 461-488. doi:10.3197/096327102129341181

[17] M. Greenwood, "Stakeholder Engagement, beyond the Myth of Corporate Responsibility," Journal of Business Ethics, Vol. 74, No. 4, 2007, pp. 315-327. doi:10.1007/s10551-007-9509-y

[18] J. A. Plaza-Úbeda, J. de-Burgos-Jiménez and E. Carmona-Moreno, "Measuring Stakeholder Integration, Knowledge, Interaction and Adaptational Behavior Dimensions,” Journal of Business Ethics, Vol. 93, No. 3, 2010, pp. 419442. doi:10.1007/s10551-009-0231-9

[19] E. C. Van Ierland and H. Weikard, "Poverty, Environment and the Natural Resource Use, Introduction to the Special Issue,” Environment and Development Economics, Vol. 13, No. 5, 2008, pp. 537-538. doi:10.1017/S1355770X08004713

[20] E. Padilla, "Climate Change, Economic Analysis and Sustainable Development,” Environmental Values, Vol. 13, No. 4, 2004, pp. 523-544. doi:10.3197/0963271042772622

[21] T. Dyllick and K. Hockert, "Beyond the Business Case for Corporate Sustainability,” Business Strategy and the Environment, Vol. 11, No. 2, 2002, pp. 130-141.

\section{doi:10.1002/bse.323}

[22] D. De Jongh, “A Stakeholder Perspective on Managing Social Risk in South Africa, Responsibility or Accountability?” The Journal of Corporate Citizenship, Vol. 15, 2004, pp. 27-31.

[23] S. Dasgupta, E.B. Lucas and D. Wheeler, "Small Plants, Industrial Pollution and Poverty, Evidence from Brazil and Mexico,” World Bank Development Research Group, Washington, 2004, Working Paper 2029.

[24] T. B. Ramos, "Development of Regional Sustainability Indicators and the Role of Academia in This Process, the Portuguese Practice,” Journal of Cleaner Production, Vol. 17, No. 12, 2009, pp. 1101-1115. doi:10.1016/j.jclepro.2009.02.024

[25] P. Prasad and M. Elmes, "In the Name of the Practical, Unearthing the Hegemony of Pragmatics in the Discourse of Environmental Management," The Journal of Management Studies, Vol. 42, No. 4, 2005, pp. 845-867. doi:10.1111/j.1467-6486.2005.00521.x

[26] R. Welford, "Environmental Strategy and Sustainable Development,” Routledge, London, 1995.

[27] J. Elkington and S. Fennel, "Partners for Sustainability," Greener Management International, Vol. 24, 1998, pp. 48-60.

[28] D. Vazquez and C. Liston-Heyes, "Corporate Discourse and Environmental Performance in Argentina,” Business Strategy and the Environment, Vol. 17, No. 3, 2008, pp. 179-193. doi:10.1002/bse.508

[29] P. Christoff, "Ecological Modernisation, Ecological Modernity,” In: S.Young, Ed., The Emergence of Ecological Modernisation, London, Routledge, 2000, pp. 209-231.

[30] A. M. Rugman and A. Verbeke, “Corporate Strategies and Environmental Regulations, an Organizing Framework," Strategy Management Journal, Vol. 19, No. 4, 2000, pp. 363-375. doi:10.1002/(SICI)1097-0266(199804)19:4<363::AID-S MJ974>3.0.CO;2-H

[31] S. Sharma and H. Vredenburg, "Proactive Environmental Strategy and the Development of Competitively Valuable Organizational Capabilities," Strategic Management Journal, Vol. 19, No. 8, 2000, pp. 729-753.

doi:10.1002/(SICI)1097-0266(199808)19:8<729::AID-SM J967>3.0.CO;2-4

[32] J. A. Aragón-Correa and S. Sharma, "A Contingent Resource-Based View of Proactive Corporate Environmental Strategy,” Academy of Management Review, Vol. 28, No. 1, 2003, pp. 71-88.

[33] S. Jain and S. Vachani, "Multinational Corporations and Global Poverty Reduction,” Edward Elgar, Cheltemhan, 2006.

[34] R. Van Tulder and A. Kolk, "Poverty Alleviation as a Corporate Issue,” In: C. Wankel, Ed., 21st Century Management, a Reference Handbook, Sage, London, 2008.

[35] European Commission, "European Commissions Communication on Corporate Social Responsibility (CSR)," 2010. http://www.ec.europa.eu/employment_social/soc-dial/csr/ index.htm 
[36] U. Idemudia, "Conceptualising the CSR and Development Debate,” Journal of Corporate Citizenship, Vol. 29, 2006, pp. 91-110.

[37] M. E. Porter and M. R. Kramer, "Strategy and Society, the Link between Competitive Advantage and Corporate Social Responsibility," Harvard Business Review, Vol. 84, 2006, pp. 78-92.

[38] G. Berger, A. Flynn, F. Hines and F. R. Johns, "Ecological Modernisation as a Basis for Environmental Policy, Current Environmental Discourse and Policy and the Implications on Environmental Supply Chain Management," The European Journal of Social Sciences, Vol. 14, No. 1, 2001, pp. 55-73.

[39] D. Arenas, J. M. Lozano and L. Albareda, "The Role of NGOs in CSR, Mutual Perceptions among Stakeholders,” Journal of Business Ethics, Vol. 88, No. 1, 2009, pp. 175197. doi:10.1007/s10551-009-0109-X

[40] UNCPSD, "Unleashing Entrepreneurship, Making Business Work for the Poor," United Nations Commission on Private Sector Development, New York, 2005.

[41] D. Vazquez-Brust, J. A. Plaza-Úbeda, C. E. Natenzon and J. de-Burgos-Jiménez, "The Challenges of Businessses Intervention in Areas with High Poverty and Environmental Deterioration, Promoting an Integrated Stakeholders Approach in Management Education," In: C. Wankel and J. Stoner, Eds., Management Education for Global Sustainability. Information Age Publishing, Charlotte, 2009.

[42] T. Donaldson and L. E. Preston, “The Stakeholder Theory of the Corporation, Concepts, Evidence, and Implications,” Academy Of Management Review, Vol. 20, No. 1, 1995, pp. 65-91.

[43] J. E. Post, L. E. Preston and S. Sachs, "Redefining the Corporation, Stakeholder Management and Organizational Wealth,” Stanford University Press, Stanford, 2002.

[44] Y. Fassin, “The Stakeholders Model Refined,” Journal of Business Ethics, Vol. 84, No. 1, 2008, pp. 113-135. doi:10.1007/s10551-008-9677-4

[45] M. Haley and A. Clayton, "The Role of NGOs in Environmental Policy Failures in a Developing Country, the Mismanagement of Jamaicas Coral Reefs,” Environmental Values, Vol. 12, No. 1, 2003, pp. 29-54. doi:10.3197/096327103129341216

[46] T. M. Jones, "Instrumental Stakeholder Theory: A Synthesis of Ethics and Economics," Academy of Management Review, Vol. 20, No. 2, 1995, pp. 404-437.

[47] S. Sharma and I. Henriques, "Stakeholder Influences on Sustainability Practices in the Canadian Forest Products Industry," Strategic Management Journal, Vol. 26, No. 2, 2005, pp. 159-180. doi:10.1002/smj.439

[48] D. Vazquez-Brust, C. Liston-Heyes, J. A. Plaza-Úbeda and J. Burgos-Jiménez, "CSR, Stakeholders' Management and Stakeholders Integration in Latin-America,," Journal of Business Ethics, Vol. 91, No. 2, 2010, pp. 171192. doi:10.1007/s10551-010-0612-0

[49] J. Hollender, "What Matters Most: Corporate Values and Social Responsibility,” California Management Review,
Vol. 46, No. 4, 2004, pp. 111-119.

[50] A. Zakhem, "Stakeholder Management Capability: A Discourse-Theoretical Approach,” Journal of Business Ethics, Vol. 79, No. 4, 2008, pp. 395-405. doi:10.1007/s10551-007-9405-5

[51] Y. Nakao, A. Amano, K. Matsumura, K. Genba and M. Nakano, "Relationship between Environmental Performance and Financial Performance: An Empirical Analysis of Japanese Corporation,” Business Strategy and the Environment, Vol. 16, No. 2, 2007, pp. 106-118. doi:10.1002/bse.476

[52] N. Walley and B. Whitehead, "It's Not Easy Being Green,” Harvard Business Review, Vol. 72, No. 3, 1994, pp. 46-51.

[53] E. Stenberg, "Stakeholder Theory Exposed," The Corporate Governance Quarterly, Vol. 2, No. 1, 1996, pp. 4-18.

[54] M. Clarkson, "A Stakeholder Framework for Analyzing and Evaluating Corporate Social Performance,” Academy of Management Review, Vol. 20, No. 1, 1995, pp. 92-117.

[55] M. J. Polonsky, “A Stakeholder Theory Approach to Designing Environmental Marketing Strategy,” Journal of Business and Industrial Marketing, Vol. 10, No. 3, 2002, pp. 29-46. doi:10.1108/08858629510096201

[56] J. Sirgy, "Measuring Corporate Performance by Building on the Stakeholders Model of Business Ethics," Journal of Business Ethics, Vol. 35, No. 3, 2002, pp. 143-162. doi:10.1023/A:1013856421897

[57] A. López-Feldman and J. WIlen, "Poverty and Spatial Dimensions of Non-Timber Forest Extraction," Environment and Development Economics, Vol. 13, No. 5, 2008, pp. 621-642.

[58] S. Harrison, D. A. Bosse and R. A. Phillips, "Managing for Stakeholders, Stakeholder Utility Functions, and Competitive Advantage," Strategic Management Journal, Vol. 31, No. 1, 2010, pp. 58-74. doi:10.1002/smj.801

[59] Pater and K. van Lierop, "Sense and Sensitivity: The Roles of Organisation and Stakeholders in Managing Corporate Social Responsibility,” Business Ethics, Vol. 15, No. 4, 2006, pp. 339-351. doi:10.1111/j.1467-8608.2006.00461.x

[60] B. A. Shiferaw, J. Okello and R. V. Reddy, “Adoption and Adaptation of Natural Resource Management Innovations in Smallholder Agriculture, Reflections on Key Lessons and Best Practices," Environmental Development Sustainability, Vol. 11, No. 3, 2009, pp. 601-619. doi:10.1007/s10668-007-9132-1

[61] W. Adger, "Vulnerability," Global Environmental Change, Vol. 16, 2006, pp. 268-281. doi:10.1016/j.gloenvcha.2006.02.006

[62] K. Allen, "Vulnerability Reduction and the CommunityBased Approach,” In: M. Pelling, Ed., Natural Disasters and Development in a Globalising World, Routledge, London, 2003, pp. 170-184.

[63] H. Eakin and M. C. Lemos, "Adaptation and the State, Latin America and the Challenge of Capacity Building under Globalization,” Global Environmental Change, Vol. 16, No. 1, 2006, pp. 7-18. 
doi:10.1016/j.gloenvcha.2005.10.004

[64] L. Scott, "Chronic Poverty and the Environment, A Vulnerability Perspective,” Chronic Poverty Research Centre, Working Paper 62, 2006.

[65] S. Boron and K. Murray, "Bridging the Unsustainability Gap, a Framework for Sustainable Development," Sustainable Development, Vol. 12, No. 2, 2004, pp. 65-73. doi:10.1002/sd.231

[66] J. Birkman, "Risk and Vulnerability Indicators at Different Scales, Applicability, Usefulness and Policy Implications," Environmental Hazards, Vol. 7, No. 1, 2007, pp. 20-31. doi:10.1016/i.envhaz.2007.04.002

[67] M. S. Chowdury, “Overcoming Entrepreneurship Development Constraints, the Case of Bangladesh,” Journal of Entreprising Communities, Vol. 1, No. 3, 2007, pp. 240251.

[68] S. Shane and Venkataraman, "The Promise of Entrepreneurship as a Field of Research," Academy of Management Review, Vol. 25, 2000, pp. 217-226.

[69] A. R. Anderson and M. Starnawska, "Research Practices in Entrepreneurship, Problems of Definition, Description and Meaning," International Journal of Entrepreneurship and Innovation, Vol. 9, No. 4, 2008, pp. 221-230. doi:10.5367/000000008786208731

[70] B. Smith, C. Matthews and M. Schenkel, "Differences in Entrepreneurial Opportunities, the Role of Tacitness and Codification in Opportuniy Identification," Journal of Small Business Management, Vol. 47, No. 1, 2009, pp. 3857.

[71] A. Fadeeva, "Promise of Sustainability CollaborationPotential Fulfilled?” Journal of Cleaner Production, Vol. 13, No. 2, 2004, pp. 165-174. doi:10.1016/S0959-6526(03)00125-2

[72] A. E. Singer, "Business Strategy and Poverty Alleviation,” Journal of Business Ethics, Vol. 66, No. 2-3, 2006, pp. 225-231. doi:10.1007/s10551-005-5587-x

[73] M. H. Morris and D. L. Sexton, “The Concept of Entrepreneurial Intensity, Implications for Company Performance,” Journal of Business Research, Vol. 36, No. 1, 1996, pp. 5-13. doi:10.1016/0148-2963(95)00158-1

[74] T. Dean and J. McMullen, "Toward a Theory of Sustainable Entrepreneurship, Reducing Environmental Degradation through Entrepreneurial Action,” Journal of Business Venturing, Vol. 2, No. 1, 2007, pp. 50-76. doi:10.1016/j.jbusvent.2005.09.003

[75] J. Brugmann and C. K. Prahalad, "Co-Creating Businesss New Social Compact," Harvard Business Review, Vol. 85, 2007, pp. 80-90.

[76] M. Kirchgeorg and M. I. Winn, “Sustainability Marketing for the Poorest of the Poor," Business Strategy and the Environment, Vol. 15, 2006, pp. 171-184. doi:10.1002/bse.523

[77] M. Halme, "Corporate Environmental Paradigms in Shift, Learning during the Course of Action at UPM-Kymmene," Journal of Management Studies, Vol. 39, No. 8, 2002, pp. 1087-1109. doi:10.1111/1467-6486.00325

[78] S. B. Banerjee, "Whose Land Is It Anyway? National Interest, Indigenous Stakeholders, and Colonial Discourses. The Case of the Jabiluka Uranium Mine,” Organization and Environment, Vol. 13, No. 1, 2000, pp. 3-38. doi:10.1177/1086026600131001

[79] T. J. Rowley and M. Moldoveanu, "When Do Stakeholders Act? An Interest and Identity-Based Model of Stakeholder Mobilization,” Academy of Management Review, Vol. 28, No. 2, 2003, pp. 204-219.

[80] F. E. Bowen, A. Newenham-Kahindi and I. Herremans, "When Suits Meet Roots, the Antecedents and Consequences of Community Engagement," Journal of Business Ethics, Vol. 95, No. 2, 2010, pp. 297-318. doi:10.1007/s10551-009-0360-1

[81] O. Helmer, "Problems in Futures Research, Delphi and Causal Cross-Impact Analysis,” Futures, Vol. 2, 1977, pp. 17-31. doi:10.1016/0016-3287(77)90049-0

[82] L. Michaelis, "The Role of Business in Sustainable Consumption,” Journal of Cleaner Production, Vol. 11, No. 8, 2003, pp. 915-921. doi:10.1016/S0959-6526(02)00160-9

[83] R. Wustenhagen, J. Hamschmidt, S. Sharma and M. Starik, "Sustainable Innovation and Entrepreneurship," Edward Elgar, London, 2008.

[84] Global Compact, "Business Guide to Partnering with Ngos and the United Nations," Global Compact and Dalberg Global Development Advisors, New York, 2008.

[85] D. Matten and A. Crane, "Corporate Citizenship, toward an Extended Theoretical Conceptualization,” Academy of Management Review, Vol. 30, No. 1, 2005, pp. 166-179. doi:10.5465/AMR.2005.15281448

[86] S. Shu, "Waste Input-Output Analysis, Concepts and Application to Industrial Ecology," Journal of Industrial Ecology, Vol.13, No. 5, 2009, pp. 835-836. doi:10.1111/j.1530-9290.2009.00157.x

[87] S. Jehan and A. Umana, "The Environment-Poverty Nexus,” Development Policy Journal, Vol. 3, 2003, pp. 5370.

[88] M. Waelkens, W. Doors and B. Criel, "The Role of Social Health Protection in Reducing Poverty: The Case of Africa," Extension of Social Security Paper No. 22, Geneva, 2005. http://www.shi-conference.de/downl/811sp1.pdf 